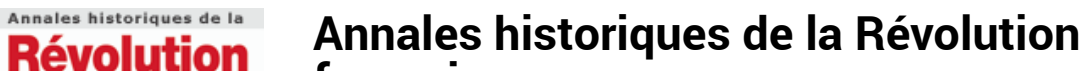

française française

324 | avril-juin 2001

Louis Charles Antoine Desaix. Officier du roi, Général

de la République

\section{Bibliographie annuelle de l'histoire de France.} Année 1999.

\section{Michel Biard}

\section{(2) OpenEdition \\ Journals}

Édition électronique

URL : https://journals.openedition.org/ahrf/1110

DOI : $10.4000 /$ ahrf. 1110

ISSN : 1952-403X

Éditeur :

Armand Colin, Société des études robespierristes

Édition imprimée

Date de publication : 1 juin 2001

Pagination : 202-203

ISSN : 0003-4436

Référence électronique

Michel Biard, «Bibliographie annuelle de l'histoire de France. Année 1999. », Annales historiques de la Révolution française [En ligne], 324 | avril-juin 2001, mis en ligne le 21 avril 2004, consulté le 24 avril 2022. URL : http://journals.openedition.org/ahrf/1110; DOI : https://doi.org/10.4000/ahrf.1110

Ce document a été généré automatiquement le 24 avril 2022.

Tous droits réservés 


\title{
Bibliographie annuelle de l'histoire de France. Année 1999.
}

\author{
Michel Biard
}

\section{RÉFÉRENCE}

Bibliographie annuelle de l'histoire de France. Année 1999, Paris, CNRS éditions, 2000, 1044 p.

1 L'année 2000 n'a pas manqué de s'achever par la parution du volume attendu de cette utile collection, volume fort de ses quelque 13000 références. 1999 voit la Révolution française rester à son niveau de l'année précédente avec $6,2 \%$ des titres recensés toutes périodes confondues, le Premier Empire gardant aussi une part comparable à 1998 avec 4,2\% (mais nul doute que ce chiffre devrait être sensiblement augmenté dans les années à venir, goût de la commémoration oblige). La nouveauté vient plutôt de la part de l'histoire révolutionnaire dans les titres recensés sous l'appellation «Histoire politique» avec seulement $14,2 \%$ là où les années précédentes lui donnaient une place aux environs de $20 \%$. Peut-être y a-t-il ici une sonnette d'alarme à tirer?

2 Ceux qui ont l'habitude de consulter cette Bibliographie annuelle ne seront guère surpris par sa forme puisque les chapitres sont très classiques et que la Révolution française est, selon la méthode déjà suivie pour les volumes précédents, éclatée en fonction des thèmes choisis (même si, au demeurant, il subsiste une partie spécifique sur la période): pour qui, par exemple, s'intéresse à la presse, la Révolution française entre dans une période qui va de 1789 à 1815; pour qui travaille sur les sciences ou la médecine, elle s'intègre dans un ensemble qui comprend les xvie, xviie et xviiie siècles avec une coupure qui s'opère en 1799-1800. Il faut également croiser les entrées d'index pour obtenir satisfaction. Ainsi quiconque désire des renseignements sur la prose qui concerne les conventionnels aura tout intérêt à ne pas regarder à «Convention», mais à «députés», il accédera de cette manière à un article de R. Barny sur le conventionnel Alexandre Deleyre rejeté dans la rubrique «doctrines politiques» et à un article du docteur Oger sur Jean-Baptiste Bo (qu'une coquille désigne sous le nom de Bro!) qui est 
classé dans la rubrique «médecine»... que ceux qui ne sont guère accoutumés au maniement de cette Bibliographie annuelle se rassurent néanmoins, elle est infiniment précieuse et leur apportera de multiples pistes, bien davantage en tout cas que les quelques bizarreries de classement susmentionnées. 